Georgia State University

ScholarWorks @ Georgia State University

UWRG Working Papers

Usery Workplace Research Group

$12-1-2014$

\title{
Unauthorized Immigration and Electoral Outcomes
}

Nicole Rae Baerg

University of Mannheim, nicole.baerg@uni-mannheim.de

Julie L. Hotchkiss

Federal Reserve Bank of Atlanta, julie.I.hotchkiss@atl.frb.org

Myriam Quispe-Agnoli

University of Georgia, mquispe@uga.edu

Follow this and additional works at: https://scholarworks.gsu.edu/uwrg_workingpapers

\section{Recommended Citation}

Baerg, Nicole Rae; Hotchkiss, Julie L.; and Quispe-Agnoli, Myriam, "Unauthorized Immigration and Electoral Outcomes" (2014). UWRG Working Papers. 148.

https://scholarworks.gsu.edu/uwrg_workingpapers/148

This Article is brought to you for free and open access by the Usery Workplace Research Group at ScholarWorks @ Georgia State University. It has been accepted for inclusion in UWRG Working Papers by an authorized administrator of ScholarWorks @ Georgia State University. For more information, please contact scholarworks@gsu.edu. 


\section{W. J. Usery Workplace Research Group Paper Series}

Working Paper 2014-12-1

December 2014

\section{Unauthorized Immigration and Electoral Outcomes}

Nicole Rae Baerg

University of Mannheim

Julie Hotchkiss

Federal Reserve Bank of Atlanta and Georgia State University

Myriam Quispe-Agnoli University of Georgia 


\title{
Unauthorized Immigration and Electoral Outcomes
}

Nicole Rae Baerg

University of Mannheim

Political Economy of Reforms

Collaborative Research Center

884 University of Mannheim

L13, 17

68131 Mannheim Germany

+49 (0) 6611813482

nicole.baerg@uni-mannheim.de
Julie Hotchkiss

(contact author)

Federal Reserve Bank of Atlanta

and Georgia State University

1000 Peachtree St NE

Atlanta, GA 30309

404-498-8198

FAX: 404-498-8956

Julie.L.Hotchkiss@atl.frb.org
Myriam Quispe-Agnoli

University of Georgia

Department of Economics

310 Herty Dr

Athens, GA 30602-6269

706-542-3667

mquispe@uga.edu

\begin{abstract}
Using a unique methodology for identifying undocumented workers across counties in the state of Georgia in the United States, we find a negative relationship between the share of unauthorized workers and the share of votes going to the Democrats in elections. Furthermore, we show that this effect is more pronounced for the presence of unauthorized immigrants than Hispanics; is stronger in counties with higher median household income; and is substantively larger in U.S. Congressional elections than Gubernatorial or Senatorial elections. We discuss which political economy theories are most consistent with this set of findings.
\end{abstract}

Key Words: voting behavior; ethnic threat; economic threat; unauthorized; undocumented; illegal; immigration

JEL Codes: $\quad$ D27 - Political Processes: Voting Behavior

P16 - Political Economy

D63 - Welfare Economics: Equity, Justice, Inequality

J23 - Labor Demand

Conflict of Interest: None of the authors have any conflict of interest (financial or non-financial) related to this body of work.

Word Count (everything except supplemental material): 9.833 


\section{Unauthorized Immigration and Electoral Outcomes}

\section{$1 \quad$ Introduction}

For many developed countries, immigration is a "hot button" election issue. In February 2014, for example, Switzerland held a national referendum "Against mass immigration." The aim of the referendum was to limit immigration by implementing new quotas for foreign workers. This antiimmigrant referendum received more than 50 percent of the popular vote. Similarly, the European Parliamentary election in 2014 demonstrated electoral support for immigration restriction across a number of countries in Europe. Far right parties from France, Greece, Holland, and Denmark gained large increases in representation in the EU legislature, much of which resulted from these parties' tough campaigns against immigration in their home countries. In Germany, where taking a stance against foreigners is politically sensitive, new anti-immigration political parties emerged with some parties putting up banners and handing out fliers against immigrants that were explicitly antiforeigner.

Unauthorized immigration has also become a divisive and controversial issue in U.S. elections. The Pew Hispanic Center estimates that roughly over 11.7 million unauthorized immigrants live in the United States illegally and comprise approximately 4 percent of the total population (Passel, Cohn, and Gonzalez-Barrera, 2013). Even though the unauthorized are without the right to vote, the presence of unauthorized immigrants poses significant economic, demographic, and welfare spending related challenges to the native, voting population and these challenges may translate into changes in election outcomes. Some politicians, for example, argue that an increase in populations of unauthorized immigrants can lead to an increase in Republican support, especially among native-born, white voters, who, because of their fears, will align themselves with the party that is strict on immigration policies. Beyond the political rhetoric, however, there is little empirical 
evidence connecting the presence of unauthorized immigrants to electoral outcomes. To our knowledge, this paper provides the first empirical investigation of the relationship between flows of unauthorized immigrants and electoral outcomes in the U.S. over time.

When it comes to immigration policy in the U.S., the Republican and Democratic parties align themselves on opposite sides of the political spectrum, at least when we examine their official platforms. The 2012 Republican Platform argues that, "Illegal immigration undermines [economic] benefits and affects U.S. workers," and, "States efforts to reduce illegal immigration must be encouraged, not attacked" (www.gop.com). The Democratic Platform, meanwhile, calls for, "comprehensive immigration reform that supports our economic goals and reflects our values as both a nation of laws and a nation of immigrants" (www.democrats.org). Most acknowledge that "comprehensive" means a plan that includes amnesty for unauthorized immigrants who are currently residing in the U.S. The Republicans, however, have no such plan and some, like Georgia Republican Representative Paul Broun, worry about a Democratic shift due to changing demographics in Southern states (Perez, 2014). Broadly speaking, the Republicans support stricter immigration policies, such as border controls and deportation, whereas Democrats support more liberal, inclusive, immigration policies.

Because of their proximity to the Mexican border, unauthorized immigration is a particularly salient electoral issue in Southern U.S. states. Inflows from Mexico alone make up more than half of all unauthorized immigrations to the U.S. (Passel, Cohn, and Gonzalez-Barrera, 2013). Although immigration is a federal level issue, starting as early as 2005, states (especially Southern states -- see Ozden, Neagu, and Mattoo, 2008) began passing their own immigration laws (NCSL, 2005). State level policies that target unlawful immigrants include requiring employers to use e-verify, an electronic program that checks the immigration status of new workers; legislation restricting drivers 
license; and enacting higher barriers for public benefits including housing, retirement benefits, and school registration. The policy domains targeted by the state are not a random sample; instead they imply that threats to jobs, demographics, and welfare spending concerns are at the forefront of the immigration debate within Southern states and at the fore in voters' minds when choosing representatives -- in a survey of Georgia residents taken in 2006, both 3 months and 1 month before the November 2006 general election, immigration was the second most important issue to voters, outranked only by the Iraq war (CCES 2006, Authors' calculations).

In order to help explain the impact of unauthorized immigration on election outcomes, we draw upon three different political economy explanations to derive a set of theoretical expectations with competing predictions. The first theory comes from models of international trade and concerns the pre-tax distributive effects of immigration that may be particularly threatening to low-skilled native workers; the second theory considers voters' feelings of race and ethic threat effects; the third theory considers post-tax redistributive concerns that link voters to unauthorized immigrants as potential or perceived "welfare magnets," or populations that use government provided services intensively and without making appropriate contributions to the public coffers. We then test a set of predictions stemming from each of these three theories using a new data set in three different electoral races: gubernatorial, senate, and U.S. congressional elections.

Using a unique employee-employer matched data set that identifies the number of undocumented workers by county in the state of Georgia between 1990 and 2011, we examine whether the share of the work force that is undocumented helps to explain changes in the Democratic vote share. In order to make sure that we are identifying the correct causal mechanism, we offer additional in- and out-migration analysis that captures demographic changes to counties and ecological inference analysis that estimates voter transition probabilities, between elections, at the 
county level. Our supplemental analysis suggests that changes in voting behavior best explains the effect of unauthorized immigration on elections rather than alternative explanations such as in- and out-migration and that vote switching is the primary mechanism underlying the aggregate analysis.

As a preview to the results, we find that a greater presence of unauthorized immigrants reduces support for Democrats. This is consistent with theories of economic, racial, and ethnic threat, and theories based on concerns over welfare spending. We also find, however, that threat effects from the unauthorized are stronger than threat effects from the Hispanic populations. This suggests that demographic changes alone are not the main cause of electoral support for the Republicans and that interestingly, status matters. ${ }^{1}$ Furthermore, we also find that richer rather than poorer counties are more likely to turn to the Republicans even when we control for county level income, race, and previous election results. This helps to distinguish between theories based on pre-tax threats and theories based on post-tax redistributive concerns. Our findings provide the most consistent support for a welfare spending threat effect. The Republicans receive the most electoral support when the population of unauthorized immigrants is high and simultaneously, the county is relatively wealthy.

\section{Theoretical Foundation and Previous Findings}

There are several theories that link the presence of a new, large, minority population with changes in natives' voting behavior in elections. Each theory is outlined here as they specifically relate to the presence of unauthorized immigrants and elections. Table 1 shows how the different theories described below lead to different predicted relationships between unauthorized immigrants and election outcomes.

[Table 1 about here]

\footnotetext{
${ }^{1}$ Status here refers to the appropriate employment documentation as opposed to other kinds of status such as class status or social standing.
} 


\subsection{Pre-tax Labor Market Competition}

An influx of people, like other international factor flows, can lead to distributional changes in factor-returns among the native-born, with some winning more from immigration than others. Factor models that depict the effects of immigration on returns to factors of production expect that an increase in undocumented workers will increase the returns to owners of capital and highly-skilled workers and threaten jobs of competing low-skilled workers (see, for example, Scheve and Slaughter, 2001 and Hanson, Scheve and Slaughter 2007). The casual mechanism here is that firms can hire the unauthorized for lower relative wages than they can the same worker with documentation (see Hotchkiss and Quispe-Agnoli 2013). As a result, firms tend to hire more of these people and less documented low-skilled workers. The greater the flow of undocumented workers, the greater the expected wage changes for the displaced population. Because voters think that wage changes and higher risks of unemployment result from higher numbers of unauthorized workers, this motivates voters to prevent the influx of these people, seeking to secure their wages and jobs through protectionist policies. Because the Republican Party is more protectionist than the Democrats, it follows that that economic explanations predict that higher levels of undocumented workers (who are generally unskilled) will translate into greater support for protectionism, especially amongst lowerskilled workers, and more votes for the Republicans. It's important to understand that it does not matter whether the presence of unauthorized workers actually lowers wages or employment opportunities of authorized workers in order for voting behavior to change, just that workers/voters think that it does. ${ }^{2}$

If, however, job competition actually reduces voters' incomes, they may become more likely to align themselves with the Democratic ideals. Furthermore, changes in undocumented workers can

\footnotetext{
${ }^{2}$ In fact, recent evidence suggests that any wage impact of the presence of undocumented workers is, at worst, negligible (see Hotchkiss, Quispe-Agnoli, and Rios-Avila, forthcoming).
} 
also change voter turnout, especially among the unemployed. Recent evidence by Burden and Wichowsky (2012) show that an increase in unemployment leads to higher levels of participation by unemployed workers at the polls. Empirically, if labor market competition is the reason for an increase in votes, and an increase in Republican votes in particular, then we expect to see this effect most strongly in poorer counties, as it is low-skilled voters that are most likely to feel economically threatened by the unauthorized.

Empirical support for this claim is mixed, however. Some authors find that the poor are no more likely to have anti-immigrant opinions (Citrin, Reingold, and Green, 1990; Espenshade and Calhoun, 1993). Alternatively, other authors find that vulnerable labor market conditions increase anti-immigration support (Borjas, Freeman, and Katz, 1992; Muller and Espenshade, 1985). Ramakrishnan (2005) finds that Republican areas are twice as likely to propose restrictive legislation than areas controlled by Democrats, especially for those voters in majority white areas. Examining anti-immigrant sentiments across-countries, Mayda (2006) finds that on average, higher skilled workers are more likely to be pro-immigration. In the U.S., Facchini and Mayda (2009) find that higher levels of high-skilled workers are positively associated with more openness to immigration. Moving away from observational studies, Hainmueller and Hiscox (2010) provide an experiment that directly tests the relationship between skill-level and attitudes on immigration. They find that both low-skilled and high-skilled workers prefer high-skilled immigrants to low-skilled immigrants. Even more recently, Malhotra, Margalit, and Mo (2013) find persuasive evidence that job competition amongst hi-tech workers make natives much more likely to support restrictive immigration policy, again lending support to the idea that labor market competition matters. 


\subsection{Racial and Ethnic Threats}

As suggested above, where you live and whom you live around matters for how you vote (Schelling 1969). In addition to how much income you and your neighbors make, the race and ethnicity of the newcomers may also play a role in shaping electoral outcomes. Power theories and theories of group threat argue that in the face of incoming minority groups, lower income groups, especially dominant racial majority groups, are more likely to defect from the Democrats and switch their votes towards to the Republicans. Furthermore, white voters in the South seem particularly electorally sensitive to demographic changes (see for example Giles and Buckner 1994; Giles and Hertz, 1994). Consequently, these theories suggest that an increase in unauthorized immigrants will pose a racial and ethnic threat and shift elections toward Republicans. In addition, we might expect to find a similar, or stronger, reaction to Mexican immigrants, generally. This is because more than half of all unauthorized immigrants to the U.S. are from Mexico (Passel, Cohn, and GonzalezBarrera, 2013). If less educated people, "are on average more nativist and culturally intolerant of foreigners" (Malhotra et al. 2013, p. 3), then we might also expect to see a more intense reaction to racial and ethnic threats in poorer and whiter counties.

Early research by Matthews and Prothro (1963) find that an increase in the number of blacks causes an increase in white voter registration in the South. Similarly, an increase in the number of blacks also affects white partisanship. Research by Giles and Hertz (1994) find that, in Louisiana between 1975 and 1990, an increase in the number of blacks is positively associated with the number of whites voting Republican (also see Giles and Buckner 1993). More recent research by Enos (2013) shows that racial enclaves and electoral effects persist in the face of inflowing minorities. He finds that not only the number of blacks but also the concentration of ethnic minorities predicts the 2008 presidential elections. In addition, making use of experimental data, Hainmueller and Hiscox (2010) 
find that non-economic reasons, such as xenophobia better predicts the publics' immigration preferences than arguments based on economic considerations, such as pre-tax labor market concerns.

\subsection{Post-Tax Redistributive Threats}

Finally, the expense of social service provision (whether actual expense or perceived expense) is often raised as a reason why unauthorized immigration is problematic (for example, see Scheve and Slaughter 2007; Becerra et al. 2012). Indeed, Tolbert and Hero (1996) find evidence that restricting access to social services is popular in those counties with either a mix of ethnic groups, counties with above average Hispanic population, or counties with a dominant white majority. If concern about the added burden that unauthorized immigrants place on the social safety net is important to voters, we expect that a higher level of unauthorized immigrants resulting in stronger support for Republicans. Furthermore, this effect should also be larger for the presence of the unauthorized, as opposed to immigrants, or Hispanics, in general. This is because voters may perceive that the unauthorized are likely to make even greater demands on the system than immigrants with proper documentation and may also perceive that the unauthorized are less likely to contribute to public funds. ${ }^{3}$

Milner and Tingley (2013) find that support for immigration policies depends on fiscal redistribution, where richer people are more likely to support immigration when welfare spending is low and less likely to support immigration when welfare spending is high. We would, therefore, expect to see a stronger reaction to the presence of unauthorized immigrants in richer counties, where taxpayers face a larger burden supporting the social safety net (in the presence of a progressive tax

\footnotetext{
${ }^{3}$ For example, the unauthorized rarely have health insurance and, therefore, make use of emergency rooms and public hospitals for the treatment of nonemergency health-related problems (Goldman et al. 2005, and Passel 2005). In addition, children of unauthorized immigrants often need additional resources in school to overcome their lack of English fluency (CBO 2007).
} 
system). To the extent that social services are supported by tax payments at the local level (e.g., police, hospitals, schools, welfare programs etc.), we also expect to see a stronger effect the more local the elections. In fact the Congressional Budget Office (CBO 2007) document that most of the fiscal burden of unauthorized immigrants falls on local, rather than Federal, coffers.

\section{Data and Analysis}

This paper estimates the effect of unauthorized immigrants on the share of the Democratic vote at the county level in Gubernatorial, U.S. Senatorial, and U.S. Congressional elections in the state of Georgia between 1990 and 2011. Undocumented workers are used as a proxy for unauthorized immigration. Undocumented workers are likely to best capture the economic threat (through the labor force) of a larger unauthorized presence.

\subsection{Undocumented Workers in Georgia}

Georgia is an excellent place to test the relationship between electoral outcomes and unauthorized immigrants. Firstly, unauthorized immigration is a prominent and state wide political issue. In Georgia, Republican legislators have initiated several laws designed to combat the growing number of unauthorized immigrants in the state of Georgia. Secondly, there is an estimated 425,000 unauthorized immigrants living in Georgia, ranking Georgia as the 7th largest host-state of unauthorized immigrants (Passel, Cohn, and Gonzalez-Barrera, 2013). The large numbers of the unauthorized and their growth in recent years makes Georgia a state where immigration policy is salient in Georgia elections. For example, consider HB87, or the "Illegal Immigration Reform and Enforcement Act of 2011." This legislation reforms investigation, verification, enforcement and penalties related to immigrants in the state of Georgia. Further, Senate Bill 160 signed by Georgia's Governor in April 2013, blocks undocumented workers from state driver's licenses, grants, public housing and retirement benefits. Finally, Georgia is a relatively poor state, ranking 33 in median 
household income (www.census.gov/acs), making voters particularly sensitive to changes in income (Gelman et al., 2007) and perhaps less tolerant of foreigners (Malhotra et al. 2013).

\subsection{Dependent Variable}

A decrease of support for Democrats within a county can occur for a number of reasons: (1) Voters can leave the Democrats to vote for either a Republican candidate or a candidate in another party, (2) Democrats can become less likely to vote, (3) Republicans can become more likely to vote, and (4) Democrats can move out or Republicans can move into the county. The first three sources of declining support for Democrats results from changes in voting -- either voting differently or voting

more or voting less. The fourth potential source does not result from changing voter behavior and can confound our interpretation. We specifically address the possibility of this confounding effect.

The dependent variable, election outcome, measures the total share of Democratic votes cast relative to the total number of votes cast for either the Democrats or the Republicans. The election data are obtained from the Georgia Secretary of State website (www.sos.ga.gov/elections). The analysis in this paper considers Gubernatorial, U.S. Senatorial, and U.S. Congressional elections by county in the state of Georgia.

\subsection{Independent Variable of Primary Interest}

As a measure of the impact of unauthorized immigrants, we use the share of workers in a county that is undocumented. One of our key contributions is that we use a unique method to measure the county level share of undocumented workers. The primary data used to construct the independent variable used in this paper are the Employer File and the Individual Wage File, compiled by the Georgia Department of Labor for the purposes of administering the state's Unemployment Insurance program. These data are highly confidential and strictly limited in their distribution. The Employer File provides an almost complete census of firms in Georgia, covering 
approximately 99.7 percent of all wage and salary workers (Committee on Ways and Means, 2004). The firm-level information includes the number of employees, and the worker file includes the worker's Social Security Number (SSN) from which we determine whether the worker is authorized to legally work or not. It is our view that this new measure of undocumented workers makes an important empirical contribution to the literature because our measure is derived from actual employment records. It is therefore most appropriate in linking the threat effects from globalization, in this case flows of undocumented workers that are actually employed in the U.S. economy, with natives' voting behavior.

Details of how the SSN is used to identify undocumented workers are contained in a supplemental appendix, available online. The abbreviated version is that there are some easily identifiable ways in which a SSN is determined to be invalid. We conclude that some of those reasons are either errors or the result of incomplete record keeping by the firm. We restrict our identification of undocumented workers to invalid SSNs that are more likely to have been generated by the worker-numbers that look valid, but are not. Workers with invalid SSNs for any other reason are not included in our count of undocumented workers; this will clearly undercount the actual number of undocumented workers. However, several robustness checks makes us confident that our sample of undocumented workers is a valid representation of the magnitude of the presence of unauthorized immigrants in a county.

In some specifications, the share of undocumented workers is replaced by the percent of the population that is Hispanic. These data are obtained from the U.S. Census Bureau Population Estimates (http://www.census.gov/popest/data/historical/index.html). 


\subsection{Additional Control Variables}

In addition to the total number of undocumented workers, we also want to account for the fact that some counties are wealthier than others. In order to do this, we include data for average county median household income. These data are gathered from the U.S. Census, Small Area Income and Poverty Estimates. We match median household income in a given county for an election year. Each variable contains one observation for each Georgia County for each year between 1989 and 2011, with the exception of the years 1990, 1991, 1992, 1994, and 1996.

For observations for each of these five missing years for each county, we impute the missing data and recover estimates of median household income (details available from the authors). We also control for the racial composition of counties using data from the U.S. Census Bureau Population Estimates (http://www.census.gov/popest/data/historical/index.html). In addition, county and election fixed effects are included.

\subsection{Methodological Details}

Figure 1 shows the Democratic vote share for Gubernatorial, Senatorial, and U.S. Congressional elections in the state of Georgia between 1990 and 2011. While the decline in Democratic vote share in Georgia over time is slight, it is observable. Figure 2 shows the dramatic growth in the share of undocumented workers in Georgia during this time period. The question is whether there is a systematic relationship between these two variables that will hold up across counties while controlling for other characteristics of the counties at the same time.

[Figures 1 and 2 about here]

In addition, Figure 3 illustrates that undocumented workers are not all concentrated in counties that are primarily Democrat or Republican. This suggests that there is some opportunity for electoral shifting across the whole state. 
[Figure 3 about here]

The statistical analysis involves estimating the following linear relationship via Ordinary

Least Squares (OLS):

$\ln \left[\frac{\text { DemShare }_{i, j, t}}{\left(1-\text { DemShare }_{i, j, t}\right)}\right]=$

$$
\beta_{0}+\beta_{1} \text { PerUndoc }_{i, t-2}+\beta_{2}^{\prime} X_{i, t}+\beta_{3} \text { DemShare }_{i, j-1}+\beta_{3} \text { DemIncumb }_{i, j}+\varepsilon_{i, j, t},
$$

where DemShare $e_{i, j, t}$, as described above, is the share of the vote in county $i$ in election $j$ in year $t$

that accrues to the Democrats. We perform a logistic transformation on the dependent variable so that it is no longer bound by zero and one; OLS estimation of the relationship is valid and we can recover predicted values that do not fall outside of the zero/one range (see Baum 2008, Madalla 1983, p. 30). The coefficients from this estimation are interpreted as the marginal effect of the regressor on the log-odds ratio of DemShare. However, since our interest is not on the odds of the Democrats receiving one hundred percent of the vote, which is what the log-odds tells us, we report the marginal effect of the regressors of interest on a percentage point change in DemShare (see notes to Table 2).

The regressor of interest, percent of undocumented workers in a particular county, has the potential of being endogenous to the democratic share of the vote in that county. While the potential for voting behavior of the population group of interest (unauthorized immigrants) affecting the outcome is not a concern here, as unauthorized immigrants do not vote, the data are not a panel of individual voting behavior. Consequently, we only know the share of votes going to Democrats at each election conditional on the composition of voters in the county during that election. In addition, out-migration of voters may occur as the result of the presence of undocumented workers, so that the results reflect changes in composition of voters within the county, rather than a change in voting behavior within a county. Analysis on in- and out-migration described below addresses this specific concern, but additionally, we lag the regressor of interest, PerUndoc, to help avoid the possibility of 
reverse causality. We use a two-year lag in order to make the potential nearness of impact consistent across different types of elections that are held at different intervals.

Other regressors, measured in the same year as the election, $X_{i, t}$, include real median household income in the county in the election year and the share of the population that is black. $\operatorname{DemIncumb}_{i, j}$ is a dummy variable indicating whether the incumbent for election $j$ is a Democrat. In addition, both election and county fixed effects are included to control for election specific (county invariant) and county specific (time invariant) determinants of the Democratic share of the vote. We also include an election-lagged value of the dependent variable to account for serial correlation between election outcomes; this would also capture the average partisanship of the electorate. $^{4}$

Relating this empirical model to the theories detailed earlier, all three theories would predict a negative estimate of $\beta_{1}$, unless job competition reduced voters' incomes making them more likely to align with Democratic. We will estimate equation (1) replacing PerUndoc with PerHispanic (percent Hispanic population in the county) in order to test predictions of the racial and ethnic and welfare and spending threat theories. Differential effects across median county incomes and types of election will also help us distinguish between these two theories, which predict differential intensities of the threat based on income and election level.

\section{$4 \quad$ Results}

Table 2 contains the main results of the paper. Equation (1) is estimated for Gubernatorial, Senatorial, and U.S. Congressional elections. The results in columns 1-3 suggest that there is a threat effect from the presence of undocumented workers: as the share of undocumented workers grows in

\footnotetext{
${ }^{4}$ Since it is well known that inclusion of a lagged dependent variable in a fixed-effect model may introduce estimation bias when the number of time periods is "small" (see Judson and Owen 1999 and Kiviet 1995), we re-estimate the model excluding the lagged dependent variable and obtain essentially the same results, suggesting the any bias in our case is quite limited.
} 
a county, support for the Democrats decreases. On average, a one-percentage point increase in the share of undocumented workers in a county results in a 1.04 percentage point decline in Democrat share of the vote in the next U.S. Congressional election. The average share of the Democrat vote in Congressional elections varies from over 50 percent through the mid-1990s to roughly 41 percent in the 2000s. In addition, while the relationship between the percent undocumented and the Democrat share of the vote is not statistically significant in the Gubernatorial and Senatorial elections, the point estimates suggest that the threat effect is stronger as it relates to Congressional candidates. This suggests that the presence of undocumented workers is more salient in Congressional elections.

[Table 2 about here]

We also see in Table 2 that the Democratic share of the vote is higher in counties with a greater share of black voters and with lower median household income, which is consistent with findings in Gelman et al. (2007) and elsewhere in the literature. As might also be expected, there is inter-temporal dependence in Democratic vote share, evidenced by the positive and significant coefficient on the lagged dependent variable suggesting that, unsurprisingly, party ID is important. The exception is in Congressional elections, where Democratic share in the previous elections appears to be negatively related to the Democratic share in the current election. However, Democratic incumbency is highly positively significant in all elections for determining share of Democratic votes.

Passel, Cohn, and Gonzalez-Barrera (2013) estimate that the unauthorized population in Georgia increased from 3.1 percent in 2000 to 4.4 percent in 2010 (a 1.3 percentage point increase). Based on the estimates in Table 2, the influx of unauthorized might account for a loss of 1.35 percent of the votes going to the Democratic for the U.S. Congressional candidate over this time period (1.3 times 1.038), which is substantially significant. 
We also estimate a number of variations on the model specification in equation (1) and obtain essentially the same results. Rather than use Democratic share of the (majority party) votes, we also constructed a supplemental liberal vote share measure, combining the Green party votes with the Democratic votes and the Libertarian votes with the Republican votes. ${ }^{5}$ We then run this "liberal" versus "conservative" measure and find no appreciable differences in the results. We also explore a model that includes both the current and lagged values of the undocumented worker share (essentially resulting in a growth analysis). Only the lagged value is statistically significant in this specification, suggesting that the level of undocumented workers, rather than the growth in undocumented workers, is important to voters. In other words, it is the stock of undocumented workers that matters to voters, rather than the flow. Also, in addition to including a lagged value of the dependent variable, we estimate the model allowing the error tern to follow an AR(1) process. Again, the results are robust and are essentially the same. In addition, we also include a measure of county population, however, the coefficient is neither substantively or statistically significant in any model specification, suggesting that the county fixed effect is picking up this and other characteristics of the county that change little over time.

The results in Table 2 indicate a decline in support for Democrats with a greater presence of unauthorized immigrants. The next sections detail the estimations designed to disentangle which of the three theories is most supported.

\subsection{Unauthorized versus Hispanic}

The economic threat and racial and ethnic threat theories suggest that we should see as much of a decline in support for the Democrats when we estimate equation (1) with percent Hispanic in

\footnotetext{
5 The Green party platform is even more extreme than Democrats in their support for unauthorized immigrants (http://www.ontheissues.org/celeb/Green_Party_Immigration.htm). The Libertarian position is more nuanced (http://www.lp.org/issues/immigration), but we code Libertarians right of center. In addition to getting similar results, the number of votes going to either of these parties in any election in Georgia is small.
} 
place of percent undocumented. A greater presence of any immigrants is theorized to threaten jobs of natives, and, as mentioned earlier, the majority of unauthorized immigrants are Hispanic; many natives, it could be argued, may not distinguish between Hispanics and the unauthorized. The welfare and spending theory, however, suggests that we should see a larger reaction by voters to percent undocumented than to percent Hispanic in the county, since the unauthorized are perceived (rightly or wrongly) to be more of a local fiscal burden. ${ }^{6}$ The coefficients on percent Hispanic are negative, as well, but significantly smaller than the impact estimated from percent undocumented, and only marginally significantly different from zero in the U.S. Congressional regression, lending support for the welfare and spending threat prediction as opposed to theories of job or racial and ethnic threats.

As another robustness check, we included both PercentUndoc and PercentHisp at the same time in a single regression. In these results, PercentHisp is never statistically significant and PercentUndoc is statistically significant at the 90 percent confidence level, with a marginal effect of -0.77 , in the Congressional regression. Since PercentHisp and PercentUndoc are correlated with one another, it's not surprising that the inclusion of PercentHisp reduces the power of PercentUndoc, although the effect is larger and its impact significant. This offers additional evidence that PercentUndoc is measuring something in addition to the presence of a larger Hispanic population.

Is it reasonable to expect that the average voter can distinguish well enough between the authorized or unauthorized status of Latinos to react differently at the polls to their presence? There is evidence that individuals at least have some confidence that they can distinguish between the unauthorized and unauthorized. In a study by Murray and Marx (2013) respondents to a survey clearly differentiate between potential threats (both economic and cultural) felt by unauthorized and authorized immigrants. Greater threats were perceived from unauthorized immigrants than from

\footnotetext{
${ }^{6}$ While the evidence of actual added burden of unauthorized immigrants on social safety nets is mixed (see Becerra et al. 2012 and CBO 2007), there is significant evidence that the media plays a powerful role in shaping perceptions about that burden (for example, see Facchini et al. 2010).
} 
authorized immigrants, and the perceptions of threat increased according to the age of the survey respondent.

\subsection{Geography of Constituents Matters}

Native-born voters concerned about perceived burdens on social services (and their tax dollars) at the local level should produce a stronger effect in elections where they feel they have the greatest influence, or in elections where the victor has more local concerns and a more local presence. All else equal, since U.S. Congressional representatives represent a much smaller geographic area than U.S. Senators or Governors, voters are more likely to personally know a Congressional candidate and a Congress person will be more responsive to local perceptions (see Fennon, 1979 and Arnold, 1990). While the lack of significance of the coefficient on PerUndoc in the Senatorial and Gubernatorial elections could simply be the result of lack of statistical power, we note the significance of other estimated regressors. Even if the estimates on PerUndoc were statistically significant, we also note that the point estimates increase substantially as the election moves from U.S. Senatorial to Gubernatorial to U.S. Congressional.

\subsection{Rich versus Poor Counties}

We also check whether or not our results are driven by differences across poor, middle, and rich counties by looking at income by terciles adjusted for inflation. The results in Table 3 indicate that reduced support for Democrats is more pronounced the wealthier a county. We argued earlier that this result would support the post-tax welfare and spending threat theory, as more wealthy voters, who are in a higher tax bracket, will object more strongly to the perception that unauthorized immigrants are straining social safety nets. It's important to note that this result does not depend on whether unauthorized immigrants are actually placing a heavy burden on social services, just that they are perceived to be doing so (see Rothschild et al. 2013). 


\section{[Table 3 about here]}

We also see in Table 3 that the stronger impact of the undocumented versus Hispanics, in general, holds across county median income levels. Also note that in Georgia median household income and the percent of the population that is Black are highly negatively correlated. We control for the population racial mix in the county in the results found in Table 3 , allowing us to the abstract from the racial mix of the population and focus on the effect across income (holding race constant).

\subsection{Robustness Exercises}

4.4.1 In- and Out-Migration. We find that as the share of undocumented workers in a county increases, the share of the vote going to the Democratic candidate in an election decreases. An alternative explanation to changing voter behavior is that, faced with an increase in the number of unauthorized immigrants, Democrats move out of the county. If Democratic voters experience greater economic threats than Republican voters (through job threat), then Democrats might flee areas with growing numbers of undocumented workers and that is why we see lower support in counties with higher shares of undocumented workers.

Since we do not have individual voting data, the best we can do to distinguish between possible alternative explanations is to investigate migration patterns. In order to do so, we make use of the Internal Revenue Service (IRS) county-to-county Migration Data. These data contain residential location information for 95 to 98 percent of the individual income tax filing population. For each county in Georgia, for each year, we know the number of people who moved into the county (inflow), the number of people who moved out of the county (outflow), and the number of people who remained in the county (non-movers). Data are available from 2005 through to 2010.

We are interested in whether the outflow in one year is significantly related to the share of undocumented workers in the previous year. It is also feasible that owners of capital (likely to be 
Republicans) move to counties with higher numbers of undocumented workers as they offer a new source of inexpensive labor. Because of this, we also consider inflow migration.

If migration patterns are the mechanism at work behind the parameter estimates in Table 2, then we should observe a positive correlation between the share of undocumented workers in the previous year and the county's outflow percentage. Of course, we do not know whether those moving out of the county are more likely to vote Democratic or Republican, therefore a positive correlation is only a necessary condition. Additionally, if owners of capital (Republicans) are moving into counties with higher shares of undocumented workers to take advantage of economic opportunities, then we should observe a positive correlation between the share of undocumented workers and the inflow percentage. Again, a positive correlation is a necessary, but not sufficient, condition.

Table 4 presents results from a logistic regression which allows us to control for other county characteristics and county and year fixed effects, in addition to the previous year's percent of unauthorized immigrants. The coefficient on lagged undocumented workers is positive in the outflow equation and negative in the inflow equation, but neither is statistically significantly different from zero. These results suggest that as the share of undocumented workers increases, Democratic defection is not, at least primarily, being driven by migration patterns. We do note however, that there are other statistically significant relationships that appear in this estimation exercise; inmigration is lower to counties with a high share of Blacks and higher in counties with a higher share of the vote going to Democrats in the previous election. This second results may be picking up growth in urban counties, which are more likely to vote Democratic.

[Table 4 about here]

4.4.2 Ecological Inference and the Georgia 2004 and 2006 Elections. One potential problem with making inferences about changing voter behavior from the results reported here is that the 
analysis relies on aggregate data and therefore cannot tell us about actual voter behavior (King, 1997). One strategy to overcome this shortcoming is to compute the voter transition probabilities - or the transitions in party preference of voters between elections at the county level— using ecological inference. In order to do this, we examine voter transition probabilities in Georgia U.S. Congressional elections between the 2004 and 2006 elections. We choose to examine the 2004 to 2006 elections for two reasons. First, as we discussed, immigration is a salient topic in Georgia and especially in the 2006 election; therefore we suspect that the native voting population was more likely to have information, worries, and concerns about illegal immigration and the potential (perceived or actual) threat effects of undocumented workers on the native born voting population between these elections. Second, because of redistricting, elections before, as well as elections after 2006, do not always have the same electoral boundaries and therefore do not have stable voting populations. By examining voter transitions between elections where the district lines are the same, we can be more confident the voting population is stable between elections than if we use elections between periods where there is redistricting (of course voters that move between elections are not accounted for, however, we have accounted for them in the in- and out-migration analysis discussed above). One significant problem with using the 2004 election, however, is that there are several uncontested elections: 6 out of 13 districts are uncontested. This makes the uncertainty in our inferences on the estimated transition probabilities for districts without a challenger either extremely large or alternatively, extremely small if the same party stays in power across elections.

In order to calculate the aggregate voter transitional probabilities from 2004 to 2006, we use Bayesian Multinomial Dirichlet estimation for ecological inference (Lau, Moore and Kellerman, 2007; Moore, 2007). The parameter estimates that we are interested in, are $\beta_{11}$ and $\beta_{21}$, or the proportion of Democrats in 2004 that voted for the Republicans in 2006 and the proportion of 
Republicans that voted Republican in 2006. Table 5 shows the data setup, where the cells are unobserved and are the estimates of interest.

[Table 5 about here]

We run the ecological inference model which estimates the proportion of voter switching (or staying) within counties. After tuning and burning in the Markov chain, we take 100,000 draws from the posterior, saving every 10th draw. Figure 4 shows the estimated density of the voter transition probabilities from voting Democrats in 2004 to voting Republican in 2006, with the mean estimate indicated on the chart. Here we see that the average probability of switching from Democrat in the 2004 election to Republican in the 2006 election is large. The mean estimated proportion of the population that voted Democrat in 2004 and switched their votes to Republican in 2006 is approximately 60 . This is not to say that an additional 60 percent of the Democrats voted for the Republicans in all elections. It is to say, however, that at the margin, of those that voted Democrat in the 2004 elections, the estimated marginal proportion of them that voted for the Republicans in the 2006 election is estimated at 60 whereas the estimated proportion that stuck with the Democrats in the 2006 election is 40. In addition, the estimated proportion of people that voted Republican in 2004 and stuck with the Republicans 2006 is approximately 80, which means that the estimated people that switched to the Democrats is less than 20 (assuming only two parties ). According to the estimated row marginal, this implies that the Democrats saw an estimated greater loss in marginal support than the Republicans, on average, across the two elections. This provides further evidence that what we are capturing in our analysis is changes in voting behavior, on net, from the Democrats to Republicans, across elections.

[Figure 4 about here] 
4.4.3 Certain Counties or Years Driving the Results? As a test of sensitivity to time period or county inclusion, we undertook a number of estimations on a sub-set of counties and years. We tested only the U.S. Congressional results and Table 6 contains the results from additional regressions. While there is some variation in precision in estimation, the negative impact of unauthorized immigrants on electoral support for the Democrats holds within each decade and among counties with larger or smaller shares of unauthorized. The lack of significance within counties with low levels of unauthorized may suggest that the impact on voters may only take hold after the share of unauthorized reaches a certain threshold. However, the marginal effect even in that sub-group is of similar magnitude to the others.

[Table 6 about here]

\section{Conclusion}

Because of a lack of data, no empirical study has been able to examine the influence of unauthorized immigration on electoral outcomes in the United States over time. By using estimates of the number of undocumented workers in counties across the state of Georgia, we find a significant negative relationship between larger shares of undocumented workers and support for the Democratic candidate. We explore several potential explanations for this relationship and find that concerns about the cost (or perceived costs) unauthorized immigrants are placing on the social safety are most likely to be driving the results.

We also provide evidence that the results are not being driven by composition bias of voters in the county, as the presence of undocumented workers is not statistically related to migration patterns. Finally, using ecological analysis we also show that the results are robust to considerations of voter transition probabilities. Richer counties instead of poorer counties are more likely to feel 
threatened by the undocumented and more likely to switch their votes to the Republicans between elections.

Our research design has a number of important features that previous observational studies are unable to exploit. First, by examining county elections within a state, we are able to control for many of the institutional features that make cross-country or cross-state comparisons difficult. Second, we know from previous work that the link between individual income and voting is particularly strong in the South (Gelman et al., 2007) and so an analysis using Georgia data is particularly well suited. Third, because we are examining the effects of a non-voting population, we need not be concerned about problems of reverse causality. Finally, by exploiting a long time series instead of examining only a snapshot of the immigration sentiments of individuals in an experimental setting or in a one-shot opinion survey, we can make inferences about the political implications of immigration patterns over time.

Previously, the lack of reliable data measuring the change in unauthorized immigrants made time series analysis difficult. Using a unique dataset that identifies undocumented workers in counties in Georgia, we are able systematically measure the threat effects of unauthorized immigration over time. That being said, our empirical analysis has some important limitations. Most notably, since we do not have individuals' votes, we cannot be sure that we do not know whether the behavior change we have identified derives from voters changing their party affiliation, or whether they are changing their voting intensity. However, we believe that we've empirically established a significant systematic relationship between changes in immigration patterns and election outcomes.

As far as implications of the results in this paper beyond the borders of Georgia, to the extent that the results are generalizable, we might expect that states with higher share of unauthorized immigrants and higher median household income would see greater degradation of support for 
Democrats. Of course, unauthorized immigration is only one issue voters consider when heading to the polls. If other issues loom larger for voters, the impact of unauthorized immigration on electoral outcomes may be diluted. However, with an announcement from the U.S. Executive Branch on November 20, 2014, that the administration will be taking several steps to defer deportation for many unauthorized immigrants, the issue of unauthorized immigration is likely to remain at the forefront of the political debate in the U.S.

Furthermore, our findings suggest that there may be a growing tension in developed countries that have aging populations. On the one hand, countries with aging populations may need to increase immigration to sustain generous welfare spending such as health and retirement benefits to natives.

On the other hand, natives, and especially wealthy voters, may react to an influx of immigrants, especially unauthorized immigrants, with higher appetites for protectionism.

\section{Achnowledgments}

The views expressed here are the authors' and not necessarily those of the Federal Reserve Bank of Atlanta or the Federal Reserve Bank System. The authors gratefully acknowledge Fernando RiosAvila, Julia Schein, Yanling Qi, and Francis Wong for research assistance. They also thank Michael Giles, Adrienne Smith, Luisa Blanco, James Lo, Yotam Margalit, Sandra Orozco-Aleman and Eric Reinhardt for helpful comments. Any remaining errors are the authors' responsibility. 


\section{References}

Arnold, Douglas. (1990) The Logic of Congressional Action. Yale University Press, New Haven and London.

Baum, C. R. (2008). "Modeling Proportions." Stata Journal 8: 299-303.

Becerra, David; Androff, David K.; Ayon, Cecilia; and Castillo, Jason T. (2012). "Fear vs. Facts: Examining the Economic Impact of Undocumented Immigrants in the U.S." Journal of Sociology \& Social Welfare 39(4).

Borjas. 2003. "The Labor Demand Curve is Downward Sloping: Reexamining the Impact of Immigration on the Labor Market." Quarterly Journal of Economics 55:702-713.

Borjas, George J., Richard B. Freeman and Lawrence F. Katz. 1992. "On the Labor Market Effects of Immigration and Trade.” National Bureau of Economic Research, Inc (8673):213-244.

Burden, Barry and Amber Wichowsky. 2012. "Unemployment and Voter Turnout.” APSA working paper, last updated (2012).

CBO. 2007. The Impact of Unauthorized Immigrants on the Budgets of State and Local Governments. Washington, D.C.: The Congressional Budget Office, December. http://www.cbo.gov/sites/default/files/cbofiles/ftpdocs/87xx/doc8711/12-6-immigration.pdf (accessed 23 February 2014).

CCES. 2006. Cooperative Congressional Election Study. http://www.icpsr.umich.edu/icpsrweb/ICPSR/studies/30141 (accessed 3 December 2014).

Citrin, Jack, Beth Reingold and Donald P. Green. 1990. "American Identity and the Politics of Ethnic Change.” Journal of Politics 52:1124-1154.

Committee on Ways and Means. 2004. Greenbook, WMCP 108-6, Section 4, April 2004.

Enos, Ryan. 2013. "The persistence of Racial Threat: evidence from the 2008 election.” Working Paper.

Espenshade, Thomas J. and Charles A. Calhoun. 1993. "An analysis of public opinion toward undocumented immigration." Population Research and Policy Review 12:189-224.

Facchini, Giovanni; Anna Maria Mayda. 2009. "Does the Welfare State Affect Individual Attitudes toward Immigrants? Evidence across Countries." The Review of Economics and Statistics 91(2): 295-314.

Facchini, Giovanni; Anna Maria Mayda; and Riccardo Publisi. 2010. "Illegal Immigration and Media Exposure: Evidence on Individual Attitudes." SSRN Working Paper (January). 
Fennon, Richard. (1979). Home Style: House Members and their Districts. Little Brown, Boston.

Gelman, Andrew, Boris Shor, Joseph Bafumi and David Park. 2007. "Rich State, Poor State, RedState, Blue State: What's the Matter with Connecticut." Quarterly Journal of Political Science 2: 345-367.

Goldman, Dana P.; James P. Smith; and Neeraj Sood. 2005. "Legal Status And Health Insurance Among Immigrants" Health Affairs 24(6): 1640-53.

Giles, Micheal W. and Kaenan Hertz. 1994. "Racial Threat and Partisan Identification.” American Political Science Review pp. 317-326.

Giles, Micheal W. and Melanie Buckner. 1993. "David Duke and Black Threat: An Old. Hypothesis Revisited.” Journal of Politics 55:702-713.

Hainmueller, Jens and Michael Hiscox. 2010. "Attitudes towards Highly Skilled and Lowskilled Immigration: Evidence from a Survey Experiment." American Political Science Review 104(1):61-84.

Hanson, Gordon; Kenneth Scheve; and Mathew Slaughter. 2007. "Public Finance and Individual Preferences Over Globalization Strategies." Economics and Politics 19(1), 1-33.

Hotchkiss, Julie L., Myriam Quispe-Agnoli and Fernando Rios-Avila. Forthcoming. "The Wage Impact of Undocumented Workers." Southern Economic Journal.

Hotchkiss, Julie L. and Myriam Quispe-Agnoli. 2013. "The Expected Impact of State Immigration Legislation on Labor Market Outcomes." Journal of Policy Analysis and Management 32(1) (Winter): 34-59.

Judson, Ruth A. and Ann L. Owen. 1999. "Estimating Dynamic Panel Data Models: A Guide for Macroeconomists." Economics Letters 65: 9-15.

King, Gary. 1997. A Solution to the Ecological Inference Problem: Reconstructing Individual Behavior from Aggregate Data. Princeton: Princeton University Press.

Kiviet, Jan F. 1995. "On Bias, Inconsistency, and the Efficiency of Various Estimators in Dynamic Panel Data Models." Journal of Econometrics 68(1): 53-78.

Lau, Olivia, Ryan T. Moore, and Michael Kellermann. "eiPack: Ecological Inference and HigherDimension Data Management.” R News 7(2/October 2007). http://www.olivialau.org/software/eiPack.html (October 29, 2014).

Maddala, G. S. (1983). Limited Dependent and Qualitative Variables in Econometrics. Cambridge: Cambridge University Press. 
Malhotra, Neil, Yotam Margalit and Cecilia Hyunjung Mo. 2013. "Economic Explanations for Opposition to Immigration: Distinguishing between Prevalence and Conditional Impact." American Journal of Political Science 57(2):391-410.

Market, John. 2010. "The Changing Face of Racial Discrimination: Hispanics as the Dominant Minority in the United States A New Application of Power-Threat Theory." Critical Sociology pp. 307-27.

Matthews, Donald R. and James W. Prothro. 1963. "Political factors and Negro voter registration in the South." American Political Science Review (2):355-367.

Mayda, Anna Maria. 2006. "Who is Against Immigration? A Cross Country Investigation of Individual Attitudes Towards Immigrants." The Review of Economics and Statistics 88(3): $510-530$.

Milner, Helen and Dustin Tingley. 2013. "The Economic and Political Influences on Different Dimensions of United States Immigration Policy." Princeton University Working Paper.

Moore, Robert. (2007) "Intrastate Robin Hoods?: Voting for Old Age Pensions in the US States". MPSA Working Paper.

Muller, Thomas and Thomas J. Espenshade. 1985. The Fourth Wave. The Urban Institute Press, Washington, D.C.NCSL. 2005. "A Review of State Immigration Legislation in 2005." URL: http://www.ncsl.org/issues-research/immig/state-laws-related-to-immigrationandimmigrants. aspx

Murray, Kate E. and David M. Marx. "Attitudes Toward Unauthorized Immigrants, Authorized Immigrants, and Refugees." Cultural Diversity and Ethnic Minority Psychology 19(3) (2013): 332-41.

NCSL. 2005. A Review of State Immigration Legislation in 2005. Washington, D.C.: National Conference of State Legislator, http://www.ncsl.org/research/immigration/immigrant-policyproject-state-legislation-117.aspx (accessed 23 February 2014).

Ozden, Caglar, Ileana Cristina Neagu and Aaditya Mattoo. 2008. "Brain Waste? Educated Immigrants in the U.S. Labor Market." Journal of Development Economics, 87(2): 255_69

Passel, Jeffrey S., D'Vera Cohn and Ana Gonzalez-Barrera. 2013. "Population Decline of Unauthorized Immigrants Stalls, May Have Reversed.” Pew Hispanic Center, Washington D.C.

Passel, Jeffery S., \& Cohn, D'Vera. 2009. "A portrait of unauthorized immigrants in the United States." Pew Hispanic Center Report, Washington, DC: Pew Research Center. 
Passel, Jeffery S. 2005. "Unauthorized Migrants: Numbers and Characteristics (background briefing prepared for the Task Force on Immigration and America's Future)" Washington, D.C., Pew Hispanic Center, June 14, 2005. available at http://pewhispanic.org/files/reports/46.pdf.

Perez, Andrew. 2014. "Rep. Paul Broun: Democrats Need 'Illegal Aliens' to Win in Georgia." The Huffington Post (7 January). http:/www.huffingtonpost.com/2014/01/07/paul-broun-illegalaliens_n_4556625.html (accessed 9/29/14).

Ramakrishnan, Subramanian Karthick. 2005. Democracy in Immigrant America: Changing Demographics and Political Participation. Stanford University Press.

Rothschild, Zachary K.; Mark J. Landau; Ludwin E. Molina; Nyla R. Branscomber; and Daniel Sullivan. 2013. "Displacing Blame Over the Ingroup's Harming of a Disadvantaged Group can Fuel Moral Outrage at a Third-party Scapegoat." Journal of Experimental Social Psychology 49(5) (September): 898-906.

Schelling, Thomas C. 1969. "Models of Segregation." American Economic Review Papers and Proceedings 59(2) (May): 488-93.

Scheve, Kenneth and Matthew Slaughter. 2001. "Labor Market Competition and Individual Preferences Over Immigration Policy." The Review of Economics and Statistics 83(1):133145.

Tolbert, Caroline J. and Rodney Hero. 1996. "Race/Ethnicity and Direct Democracy: An Analysis of California's Illegal Immigration Initiative.” The Journal of Politics 58:806-818. 
Table 1. Theoretical predictions about the relationship between the presence of unauthorized immigrants and election outcomes.

\begin{tabular}{lccc}
\hline Expected Relationship & $\begin{array}{c}\text { Pre Tax } \\
\text { Income } \\
\text { Effects }\end{array}$ & $\begin{array}{c}\text { Racial and } \\
\text { Ethnic } \\
\text { Threats }\end{array}$ & $\begin{array}{c}\text { Welfare } \\
\text { Spending } \\
\text { Threats }\end{array}$ \\
\hline Reduced support for Democrats & Maybe & Yes & Yes \\
$\begin{array}{l}\text { Impact greater for presence of } \\
\text { unauthorized than for Hispanic }\end{array}$ & No & No & Yes \\
$\begin{array}{l}\text { Impact strongest in when constituency } \\
\text { is more geographically local }\end{array}$ & & & Yes \\
\begin{tabular}{l} 
Impact greater in richer counties \\
\hline
\end{tabular} & No & No & Yes \\
\hline
\end{tabular}


Table 2. OLS regressions by type of election; dep. var. is the logistic transformation of the share of vote going to Democrat candidate.

\begin{tabular}{|c|c|c|c|c|c|c|}
\hline \multirow[b]{2}{*}{ Variable } & \multicolumn{3}{|c|}{ Percent Undocumented as Regressor of Interest } & \multicolumn{3}{|c|}{ Percent Hispanic as Regressor of Interest } \\
\hline & Senatorial & Gubernatorial & Congressional & Senatorial & Gubernatorial & Congressional \\
\hline PercentUndoc $_{t-2}$ & $\begin{array}{c}-1.856 \\
(1.380) \\
{[-0.414]}\end{array}$ & $\begin{array}{c}-2.362 \\
(1.460) \\
{[-0.534]}\end{array}$ & $\begin{array}{c}-4.646^{* * *} \\
(1.757) \\
{[-1.038]}\end{array}$ & -- & -- & - \\
\hline PercentHisp $_{t-2}$ & -- & -- & -- & $\begin{array}{c}-0.117 \\
(0.499) \\
{[-0.026]}\end{array}$ & $\begin{array}{c}-0.937 \\
(0.659) \\
{[-0.211]}\end{array}$ & $\begin{array}{c}-1.840 * \\
(0.992) \\
{[-0.409]}\end{array}$ \\
\hline RealMHI $_{t}(\$ 00000)$ & $\begin{array}{c}-0.375 \\
(0.307) \\
{[-0.084]}\end{array}$ & $\begin{array}{c}-1.664 * * * \\
(0.455) \\
{[-0.376]}\end{array}$ & $\begin{array}{c}-0.358 \\
(0.985) \\
{[-0.080]}\end{array}$ & $\begin{array}{c}-0.372 \\
(0.314) \\
{[-0.083]}\end{array}$ & $\begin{array}{c}-1.840 * * * \\
(0.462) \\
{[-0.415]}\end{array}$ & $\begin{array}{c}-0.548 \\
(1.010) \\
{[-0.122]}\end{array}$ \\
\hline PercentBlack $_{t}$ & $\begin{array}{c}1.699 * * * \\
(0.354) \\
{[0.379]}\end{array}$ & $\begin{array}{c}2.313 * * * \\
(0.449) \\
{[0.523]}\end{array}$ & $\begin{array}{c}3.145 * * * \\
(0.804) \\
{[0.709]}\end{array}$ & $\begin{array}{c}1.698 * * * \\
(0.353) \\
{[0.379]}\end{array}$ & $\begin{array}{c}2.265 * * * \\
(0.465) \\
{[0.517]}\end{array}$ & $\begin{array}{c}3.209 * * * \\
(0.828) \\
{[0.713]}\end{array}$ \\
\hline DemShare $_{j-1}$ & $\begin{array}{c}2.288 * * * \\
(0.174)\end{array}$ & $\begin{array}{c}0.597 * * \\
(0.242)\end{array}$ & $\begin{array}{c}-0.287 * * * \\
(0.100 ¥)\end{array}$ & $\begin{array}{c}2.306 * * * \\
(0.179)\end{array}$ & $\begin{array}{l}0.102^{*} \\
(0.055)\end{array}$ & $\begin{array}{c}-0.291 * * * \\
(0.098)\end{array}$ \\
\hline DemIncumb $_{i, j}=0,1$ & $\begin{array}{c}0.354 * * * \\
(0.025)\end{array}$ & $\begin{array}{c}0.128 * * * \\
(0.047)\end{array}$ & $\begin{array}{c}0.412 * * * \\
(0.038)\end{array}$ & $\begin{array}{c}0.361 * * * \\
(0.025)\end{array}$ & $\begin{array}{c}0.127 * * * \\
(0.046)\end{array}$ & $\begin{array}{c}0.409 * * * \\
(0.038)\end{array}$ \\
\hline Constant & $\begin{array}{c}-1.875 * * * \\
(0.179)\end{array}$ & $\begin{array}{c}-0.658 * * \\
(0.263)\end{array}$ & $\begin{array}{c}-0.391 \\
(0.550)\end{array}$ & $\begin{array}{c}-1.903 * * * \\
(0.184)\end{array}$ & $\begin{array}{c}-0.563 * * \\
(0.263)\end{array}$ & $\begin{array}{l}29.41 * * \\
(14.168)\end{array}$ \\
\hline Observations & 954 & 795 & 1440 & 954 & 795 & 1440 \\
\hline Within $\mathrm{R}^{2}$ & 0.827 & 0.732 & 0.2618 & 0.826 & 0.745 & 0.262 \\
\hline
\end{tabular}

Notes: Dependent variable is the logistic transformation of the share of vote in each election going to the Democratic candidate.

Estimation also includes election and county fixed effects. Robust standard errors in parentheses, marginal effects in brackets. $* * * p$ $<0.01,{ }^{*} \mathrm{p}<0.05,{ }^{*} \mathrm{p}<0.1$. Percentage variables range between zero and one. An alternative specification excludes the lagged dependent variable and allows the error term to follow an AR(1) process; the results are essentially the same. Total number of unique counties is 159 . The marginal effect for county $i$ for a change in regressor $k$ are calculated as follows:

$\frac{\partial \text { DemShare }_{i}}{\partial X_{k}}=\left(-\hat{\beta}_{k}\right) \frac{e^{-\left(\widehat{\mathrm{B}} \Omega_{i}\right)}}{\left[1+e^{-\left(\hat{\mathrm{B}} \Omega_{i}\right)}\right]^{2}}$, where $\widehat{\mathrm{B}} \Omega_{i}$ is the linear prediction for county $i$ from the OLS estimation of the logistic transformation. 
Table 3. OLS regressions; coefficients on Percent Undocumented and Percent Hispanic by county median household income terciles (inflation-adjusted values).

\begin{tabular}{lccc}
\hline Variable & $\begin{array}{c}\text { Low Income } \\
\leq \$ 37,000\end{array}$ & $\begin{array}{c}\text { Middle Income } \\
>\$ 37,000, \\
\leq \$ 44,000\end{array}$ & $\begin{array}{c}\text { High Income } \\
>\$ 44,000\end{array}$ \\
\hline PercentUndoc $_{t-2}$ & $-3.658^{*}$ & $-6.413^{*}$ & $-20.729^{* *}$ \\
& $(2.026)$ & $(2.453)$ & $(10.523)$ \\
& {$[-0.881]$} & {$[-1.402]$} & {$[-4.408]$} \\
PercentHisp $_{t-2}$ & -0.604 & $-2.911^{*}$ & $-3.918^{* *}$ \\
& $(1.028)$ & $(1.127)$ & $(0.389)$ \\
& {$[-0.145]$} & {$[-0.620]$} & {$[-0.837]$} \\
Observations & 527 & 443 & 470 \\
\hline
\end{tabular}

Notes: Dependent variable is the logistic transformation of the share of vote in Congressional elections going to the Democratic candidate. See notes to Table 2. Other regressors include median household income in county; percent of county population that is black; lagged dependent variable; an indicator for Democrat incumbent; and county and election fixed effects. 
Table 4. OLS regressions of county outmigration and immigration, 2005-2010.

\begin{tabular}{|c|c|c|}
\hline Dependent Variable $=$ & Out-migration & In-migration \\
\hline (Percent Undoc. $)_{t-1}$ & $\begin{array}{c}0.6260 \\
(1.0091) \\
{[0.0408]}\end{array}$ & $\begin{array}{c}-0.3372 \\
(1.2413) \\
{[-0.0246]}\end{array}$ \\
\hline$(\text { Real MHI })_{\mathrm{t}}$ & $\begin{array}{l}0.3915^{*} \\
(0.2069) \\
{[0.0255]}\end{array}$ & $\begin{array}{c}0.3405 \\
(0.3261) \\
{[0.0248]}\end{array}$ \\
\hline$(\text { Percent Black })_{\mathrm{t}}$ & $\begin{array}{c}-1.0757^{*} \\
(0.6253) \\
{[-0.0701]}\end{array}$ & $\begin{array}{c}-2.9224 * * * \\
(0.9524) \\
{[-0.2128]}\end{array}$ \\
\hline$(\text { Dependent Variable })_{t-1}$ & $\begin{array}{c}-2.7607 * * \\
(0.8702) \\
{[-0.1800]}\end{array}$ & $\begin{array}{c}1.4470 \\
(0.9404) \\
{[0.1054]}\end{array}$ \\
\hline $\begin{array}{l}\text { (Percent of vote going to } \\
\text { Democrats in most } \\
\text { recent Congressional } \\
\text { election) } \text { t }-1^{-}\end{array}$ & $\begin{array}{c}0.0241 \\
(0.0209) \\
{[0.0016]}\end{array}$ & $\begin{array}{c}0.1493 * * * \\
(0.0306) \\
{[0.0109]}\end{array}$ \\
\hline Constant & $\begin{array}{c}-2.2681 * * * \\
(0.2237)\end{array}$ & $\begin{array}{c}-1.9768 * * * \\
(0.3370)\end{array}$ \\
\hline $\begin{array}{l}\text { Observations } \\
\text { Within R squared }\end{array}$ & $\begin{array}{c}795 \\
0.132\end{array}$ & $\begin{array}{c}795 \\
0.357\end{array}$ \\
\hline
\end{tabular}

Notes: Dependent variable is the logistic transformation of the percent of the county's population that either out- or in-migrated in a given year. Estimation also includes year and county fixed effects. Standard errors in parentheses, marginal effects in brackets. ${ }^{* * *} \mathrm{p}<0.01,{ }^{* *} \mathrm{p}<0.05,{ }^{*} \mathrm{p}<0.1$. Total number of unique counties is 159 . Robust standard errors are estimated to correct for heterskedasticity. 
Table 5: Voter Transition Probabilities for Congressional Elections 2004 to 2006

\begin{tabular}{l|c|c|c}
\hline & Republicans 2006 & Democrats 2006 & Totals \\
\hline Democrats 2004 & $\beta_{11}$ & $\beta_{12}$ & Total \\
\hline Republicans 2004 & $\beta_{21}$ & $\beta_{22}$ & Total \\
\cline { 2 - 3 } & Total & Total & \\
\hline
\end{tabular}

Table 6. OLS regressions; coefficients on Percent Undocumented (PercentUndoc P $_{t-2}$ ) for different sub-groups of data, U.S. Congressional elections.

\begin{tabular}{lcc}
\hline Sub-group & $\begin{array}{c}\text { Coefficient on } \\
\text { PercentUndoc } t-2\end{array}$ & $\begin{array}{c}\text { Number of } \\
\text { Observations }\end{array}$ \\
\hline Full Sample & $-4.646^{* * *}$ & 1,440 \\
& $(1.757)$ & \\
& {$[-1.038]$} & 590 \\
Years 1990-1998 & $-4.7644 * * *$ & \\
& $(1.3808)$ & 850 \\
Years 2000-2010 & {$[-1.0400]$} & \\
& $-7.3296 * *$ & \\
& $(3.5994)$ & 668 \\
Counties with less than the median percent & {$[-1.6621]$} & \\
undocumented (median=0.51\%) & -5.9737 & \\
& $(7.9856)$ & 772 \\
Counties with more than the median percent & $-1.3874]$ & \\
undocumented (median=0.51\%) & $-5.7461 * * *$ & \\
& $(1.6711)$ & \\
\hline
\end{tabular}

Notes: Dependent variable is the logistic transformation of the share of vote in Congressional elections going to the Democratic candidate. See notes to Table 2. Other regressors include median household income in county; percent of county population that is black; lagged dependent variable; an indicator for Democrat incumbent; and county and election fixed effects. 
Figure 1. Electoral Results by Democratic vote share and by election type
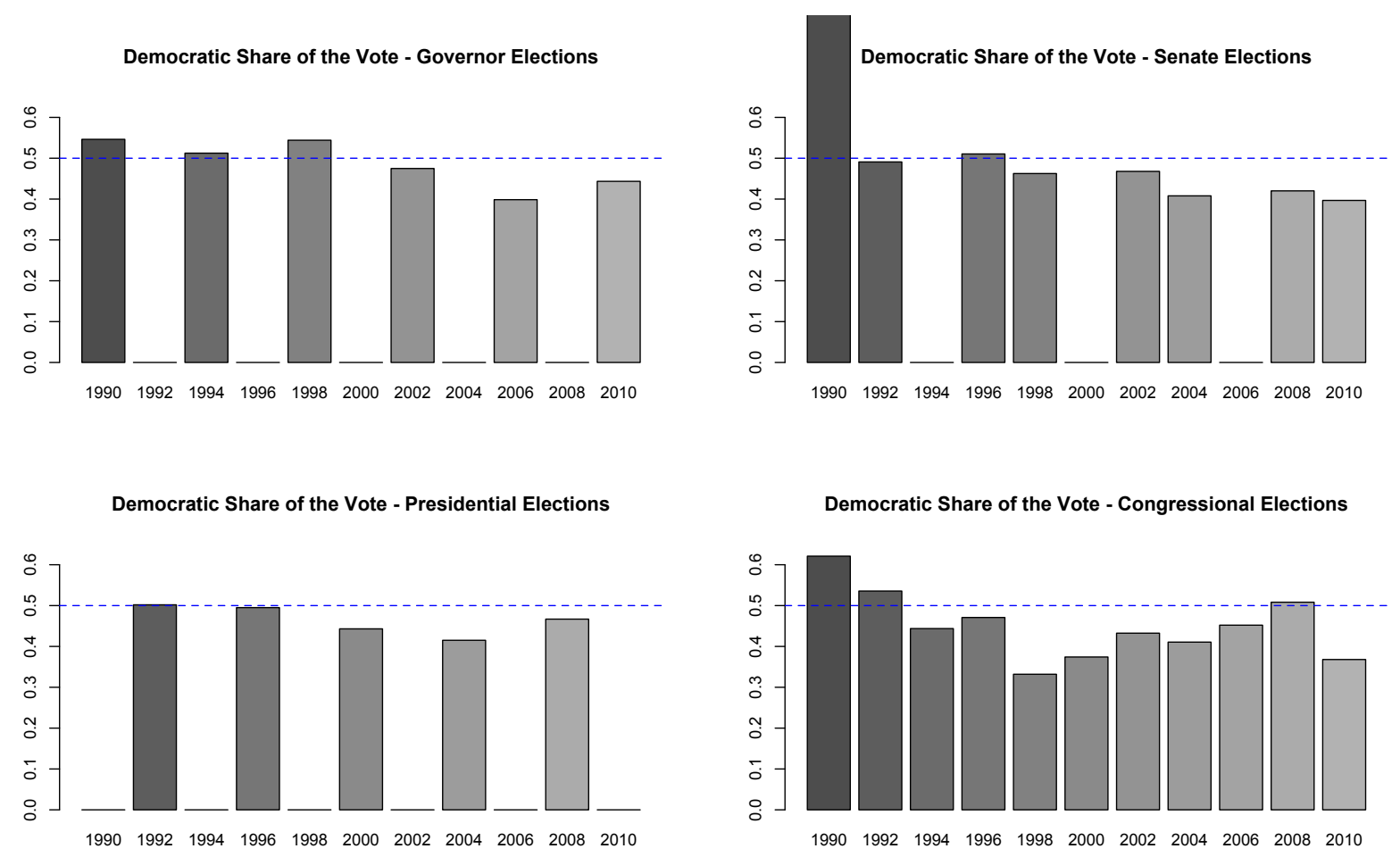

Figure 2. Growth in Unauthorized Workers in Georgia (authors' classification)

Share of Undocumented Workers in Georgia, 1990-2010

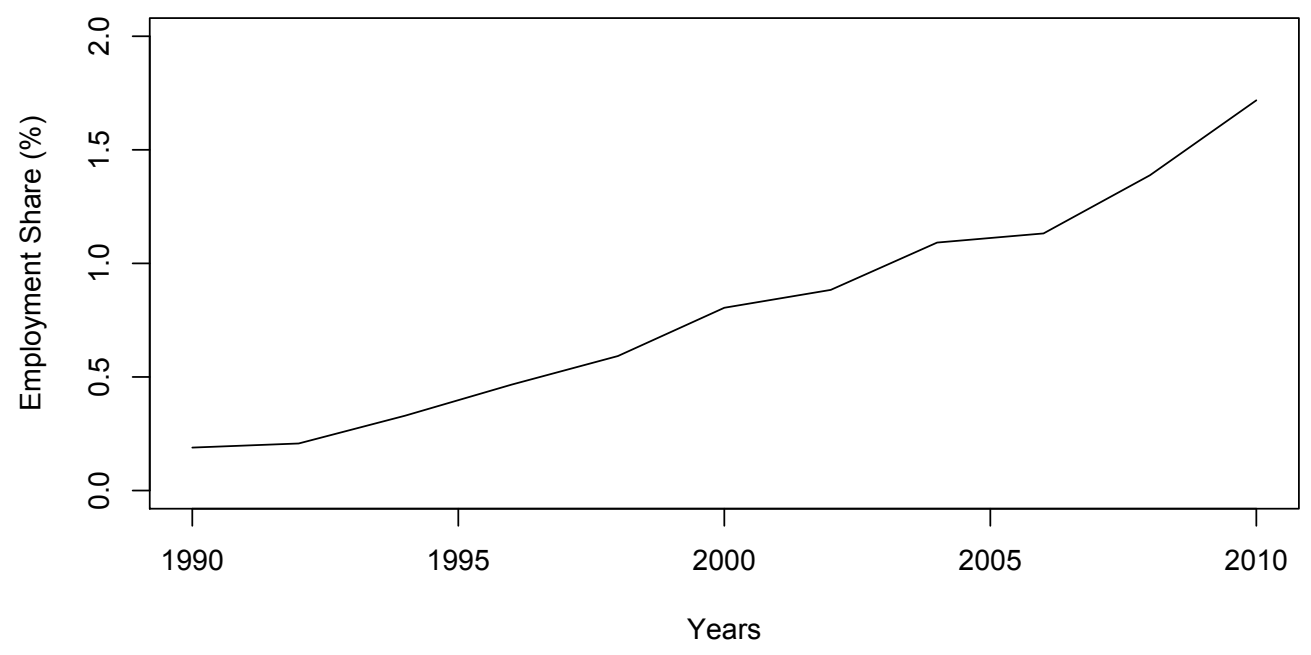


Figure 3. Distribution of Undocumented Workers and Vote Share Across Georgia, 2010.

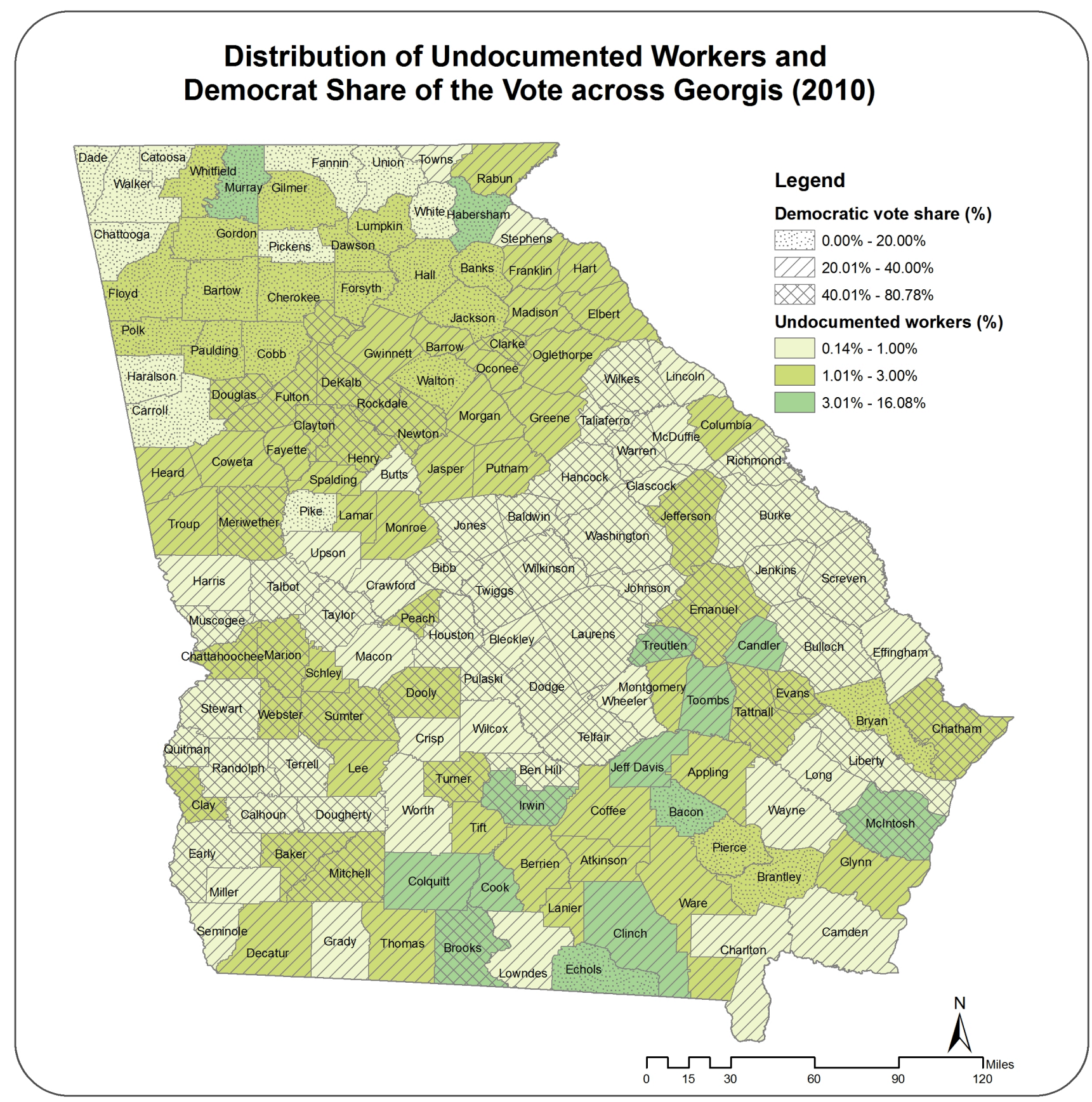




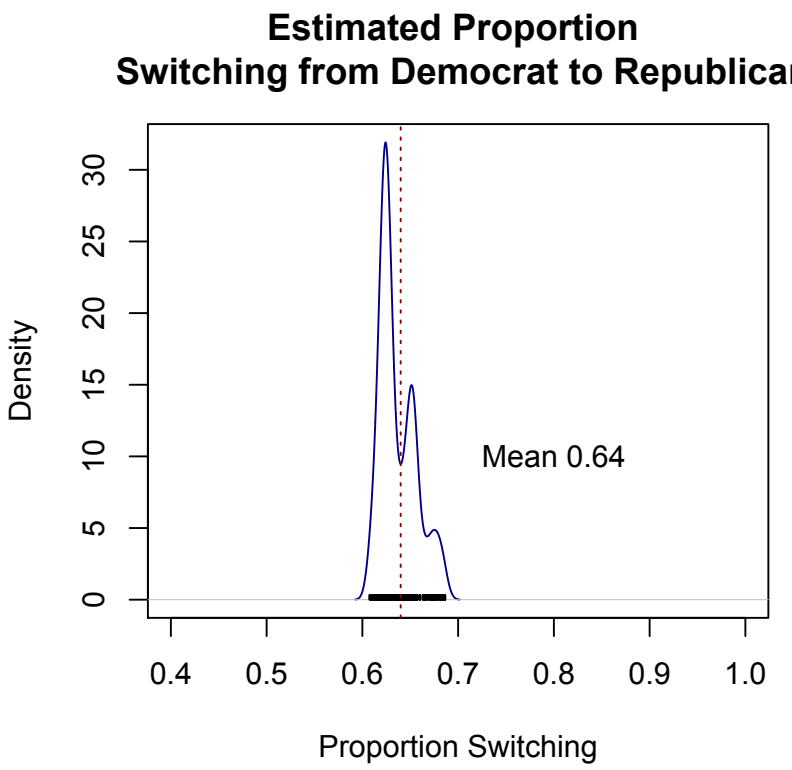

Estimated Proportion Staying Republican

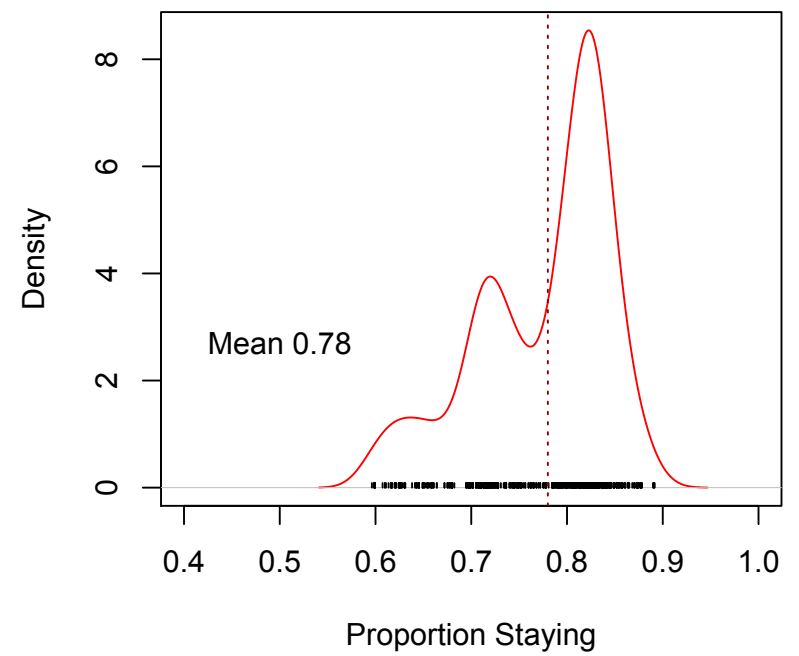

Figure 4. Estimated Voter Transition Probabilities in Congressional Elections 2004 to 2006 Notes: Multinomial Dirichlet estimates of Democratic Switching and Republican Staying in the 2004 to 2006 Congressional Elections in Georgia Counties. Estimates suggest that Democrats are likely to switch to the Republicans in the 2006 election. Estimates using momc methods in the R package eiPack. 


\section{Supplemental Appendix \\ for Unauthorized Immigration and Electoral Outcomes}

Every quarter, employers file a report with the state Department of Labor detailing all wages paid to workers who are covered under the Social Security Act of 1935. Each worker on this report is identified by his/her social security number (SSN). There are several known characteristics of a valid social security number, so we check whether each number conforms to these characteristics. ${ }^{1}$ The first three numbers of the SSN are the Area Number. This number is assigned based on the state where the SSN application was made. The lowest Area Number is 001 and the highest Area Number ever issued, as of December 2006, is 772 . Using information provided by the SSA, we can determine the dates at which area numbers between 691 and 772 are first assigned. Any SSN with an Area Number equal to 000 , greater than 772 , or which shows up before the officially assigned date, is considered invalid. The second piece of a SSN consists of the two-digit Group Number. The lowest group number is 01 , and they are assigned in non-consecutive order. Any SSN with a Group Number equal to 00 or with a Group Number that appears in the data out of sequence with the Area Number is considered invalid. The last four digits of a SSN are referred to as the Serial Number. These are assigned consecutively from 0001 to 9999 . Any SSN with a Serial Number equal to 0000 is invalid.

In 1996 the Internal Revenue Service (IRS) introduced the Individual Tax Identification Number (ITIN) to allow individuals who had income from the U.S. to file a tax return (the first ITIN was issued in 1997). It is simply "tax processing number," and does not authorize an individual to work in the U.S. Employers are instructed by the IRS to "not accept an ITIN in place of a SSN for employee identification for work." An ITIN is only available to resident and nonresident aliens who are not eligible for U.S. employment and need identification for tax purposes. ITIN numbers have a

\footnotetext{
${ }^{1}$ Starting in June 2011, the Social Security Administration began constructing SSNs in a random fashion, so this identification of whether a SSN is valid or not is no longer possible.
} 
"9" in the first digit of the Area Number and a "7" or "8" in the first digit of the Group Number. Anyone with this numbering scheme we identify as having an invalid Area Number. Interestingly, the percent of SSNs with high area numbers that also match the ITIN numbering scheme has risen from about one percent in 1997 to over 60 percent by the end of 2006 .

A series of SSNs were de-commissioned by the Social Security Administration because they had been put on fake Social Security Cards used as props to sell wallets. Apparently, some people who purchased the wallets thought the fake Social Security Cards were real and started using them as their own. If any of these 21 "pocketbook" SSNs appear in the data, they are considered invalid, although their frequency is so low as to be inconsequential. In addition, a number of SSNs are exactly equal to the employer identification number. These are invalid, primarily because they have too few digits. In any instance where a SSN is used for more than one person on a firm's UI wage report or does not have the required number of digits (including zeros), the SSN is marked invalid.

The possibility that someone fraudulently uses a valid SSN assigned to someone else poses a special problem. First of all, the SSN will show up multiple times across firms in one quarter for workers with different surnames (the wage report includes the first three characters of the workers' surnames). With this information alone, it is not possible to know which worker is using the SSN fraudulently and who the valid owner of the number is. If one of the SSN/surname pairs shows up in the data initially in a quarter by itself, this is the pair that is considered valid and all other duplicates (with different surnames) are marked invalid.

This measurement strategy clearly undercounts the actual number of undocumented workers in Georgia, but we can draw on a couple of sources of external data to show that our sample of undocumented workers closely represents the presence of unauthorized immigrants in the state of Georgia. First of all, the rate of growth seen in both the number and percent of undocumented 
workers identified in Georgia matches closely the rate of growth in the Social Security Administration's (SSA) earnings suspense file (ESF). The ESF is a repository of Social Security taxes paid by employers that cannot be matched to a valid name or SSN. It is widely believed that this growth in the ESF reflects growing incidence of unauthorized work in the United States (Bovbjerg, 2006). Figure S1 plots the number of workers (panel a) and the percent of workers (panel b) identified as undocumented along with the size of the ESF (we plot numbers only through 2006, since that is the last year for which the ESF data are available). This figure shows a remarkable consistency between the growth seen in workers identified as undocumented and the ESF.

As mentioned earlier, data suggest that between 40 and 60 percent of Mexicans in the United States are undocumented, and that 61 percent of unauthorized immigrants come from Mexico. Clearly not all Hispanics are undocumented, or vice versa; however, using weighted data from the Current Population Survey (CPS), we calculate the average annual growth in total workers and total number of foreign-born, Hispanic workers in the United States and in Georgia to compare growth rates to those in our sample in order to provide a second validity test for our measure of the presence of unauthorized immigrants in Georgia. These results are reported in Table S1. The work force in GA grew faster over the period than the U.S. work force (2.9 vs. 1.5 percent, respectively). In addition, the number of foreign-born, Hispanic workers in the United States grew faster ( 8 percent per year) than the overall work force; other researchers have also documented this phenomenon (see Passel \& Cohn, 2009). But most importantly for our purposes is that the growth rate of foreign-born, Hispanic workers in Georgia (roughly 27 percent per year), which is much larger than in the United States overall (also see Passel and Cohn, 2009), is similar to the growth in the number of workers in Georgia we classify with our measurement strategy as undocumented. We also observe a similarly large growth rate in the number of foreign-born, Hispanic workers with less than a high school 
degree (21 percent), among which we might expect a larger share of undocumented workers than among foreign-born, Hispanics in general.

Figure S1. Growth in the earnings suspense file and the total number and percent of workers identified as undocumented in Georgia, 1990 to 2006.
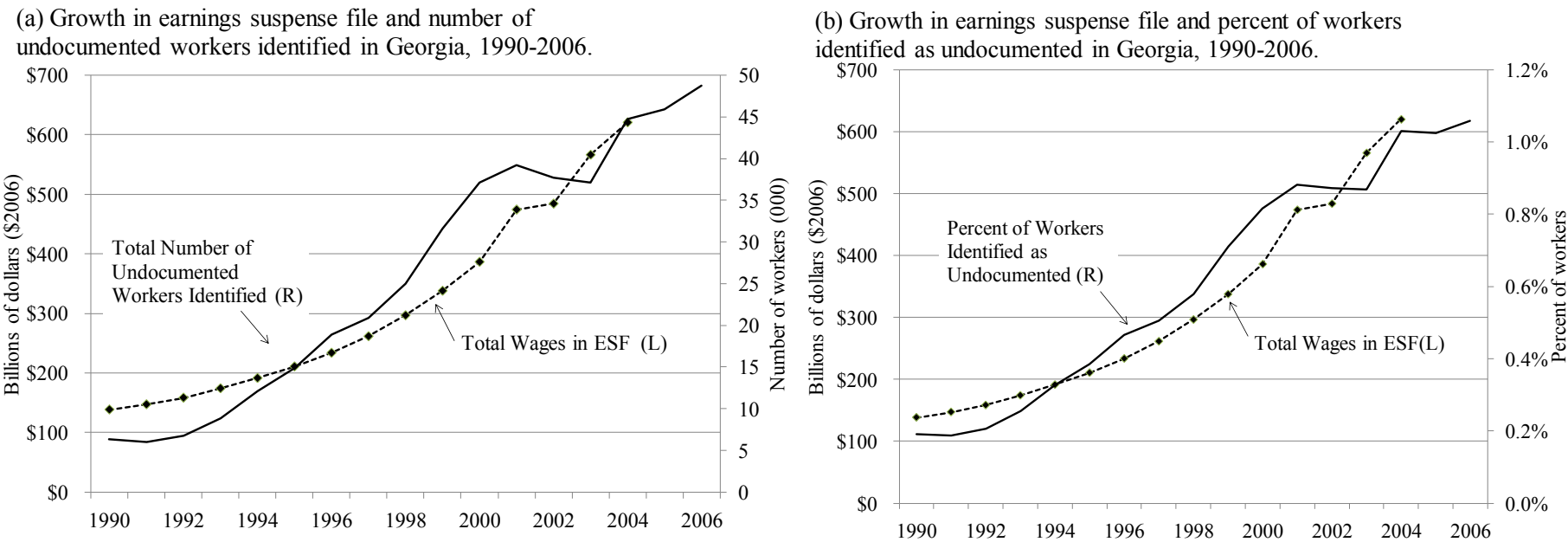

Source: Huse (2002) for estimates 1990-2000, Johnson (2007) for estimates 2001-2004, and authors' calculations. Dollar estimates reflect 2006 values, using the PCE chain-weighted deflator.

Table S1. Average annual growth, 1994-2008, in U.S. and GA employment, Hispanic workers, and workers identified as undocumented.

\begin{tabular}{ll}
\hline Average Annual Growth Rate of: & \\
\hline Total number of workers in the U.S. & $1.43 \%$ \\
Total number of foreign born, Hispanic workers in the U.S. & $7.26 \%$ \\
& \\
& $2.82 \%$ \\
Total number of workers in Georgia & $20.74 \%$ \\
Total number of foreign born, Hispanic workers in Georgia & \\
& $29.65 \%$ \\
\hline
\end{tabular}

Source: Current Population Survey, Basic Survey (March), 1994-2008; and authors' calculations. Note: 1994 is used as the base year since is the first year the Current Population Survey has a reliable indicator of Hispanic ethnicity 


\section{References}

Bovbjerg, B. D. (2006). "Social Security numbers: Coordinated approach to SSN data could help reduce unauthorized work: Testimony before the Subcommittees on Social Security and on Oversight, Committee on Ways and Means, House of Representatives.GAO-06-458T." Washington, DC: Government Accountability Office. Retrieved December 15, 2008, from http://www.gao.gov/new.items/d06458t.pdf.

Huse, J. G. 2002. "Status of the Social Security Administration's Earnings Suspense File," Congressional Response Report A-03-03-23038, November. Accessed 2008. http://www.ssa.gov/oig/ADOBEPDF/A-03-03-23038.pdf.

Johnson, M. 2007. “The Growing Cost of Illegal Immigrants to Social Security: Unprecedented Growth in Social Security’s Earnings Suspense File.” Mimeo, March. Accessed 2008. http://www.tscl.org/NewContent/102880.asp.

Passel, Jeffery S., \& Cohn, D'Vera. 2009. "A portrait of unauthorized immigrants in the United States." Pew Hispanic Center Report, Washington, DC: Pew Research Center. 